\title{
Postcolonialism Revisited: Representations of the Subaltern in Fadia Faqir's Pillars of Salt
}

\author{
Tawfiq Yousef \\ Middle East University, Amman, Jordan
}

\begin{abstract}
Postcolonial theory is a well-established critical approach that addresses issues such as the quest for identity, the significance of land, homelessness, resistance, and the encounter between the colonized and the colonizers. This paper examines the postcolonial elements utilized by the Anglo-Jordanian novelist Fadia Faqir in her novel Pillars of Salt. It discusses the novel's themes and techniques associated with postcolonialism as a literary theory and as a critical approach. Being a postcolonial text, the novel shows the writer's attempt at writing back in response to the colonial past with its power structures and social hierarchies. Thematically, the novel is analyzed with special reference to such topics as the subaltern, Anglo-Jordanian ties, language, otherness, and identity. The paper also traces the continuity of postcolonial discourse in Faqir's novel and gives a short survey of the historical events that provide the background to the main events in this essentially postcolonial work.
\end{abstract}

Keywords: postcolonialism, subaltern, Faqir

\section{Introduction and General Background}

The concept "postcolonialism" was originally used after World War II to designate the post-independence period. In its dictionary meaning "postcolonialism" means "occurring or existing after the end of colonial rule" (Oxford Dictionaries, 2015). Thus, it stands for the period following a state of colonialism. However, any definition of postcolonialism will be further complicated by the two different meanings of the hyphenated and the unhyphenated forms of the word. Sawant (2012) observes that "the hyphenated term 'post-colonialism' marks a historical period as is suggested by phrases like 'after colonialism', after independence'... whereas the term 'postcolonialism' refers to all characteristics of a society or culture from the time of colonization to the present" (p. 120). The term is also replete with various connotations or significations such as the end of colonialism, anti-colonial movement, and the period after colonialism, etc. Childs and Williams (1996) explain that "the obvious implication of the term post-colonial is that it refers to a period coming after the period of colonialism" (p. 1).

Ashcroft, Griffiths, and Tiffin (2004) maintain that the "semantic basis of the term 'post-colonialism' might seem to suggest a concern only with the national culture after the departure of the imperial power" (p. 1). Instead, they use the term "to cover all the culture affected by the imperial process from the moment of colonization to the present day" (p. 1). Gilbert and Tompkins (1996) have also clarified that,

The term post-colonialism - according to a too-rigid etymology — is frequently misunderstood as a temporal concept, meaning the time after colonialism has ceased, or the time following the politically determined Independence Day on

Tawfiq Yousef, professor, Ph.D., English Department, Middle East University. 
which a country breaks away from its governance by another state... Post-colonialism is, rather, an engagement with, and contestation of, colonialism's discourses, power structures, and social hierarchies... A theory of post-colonialism must, then, respond to more than the merely chronological construction of post-independence, and to more than just the discursive experience of imperialism. (p. 2)

Post-colonialism is then a subtle term that responds to more than a chronological construction of post-independence period. As Lawson (1992) states, postcolonialism is a "politically motivated historical-analytical movement which engages with, resists and seeks to dismantle the effects of colonialism in the material, historical, cultural-political, pedagogical, discursive, and textual domains" (quoted in Gilbert \& Tompkins, 1996, p. 2).

In its more general sense, postcolonialism is the study of the European and sometimes American, direct global domination whether during the period of colonization or that of the post-colonial period. More specifically, it is the period following the 1950s when many colonized countries started to gain their independence from imperial powers. It examines how the emerging nations grapple with their own problems following the period of colonization. It refers to a movement against marginalization, subjugation, and suppression and how the newly decolonized nations incorporate or reject the Western cultural values and norms. The main concerns of postcolonialism include the political, social, cultural, and psychological effects of colonial history on the colonized peoples and countries.

Postcolonialism or postcolonial study is a way of responding to the cultural and political legacies of colonialism (or forced settlement of one group in another country) and imperialism (the formation of an empire through the domination of one country over several nations). It is a reaction to the occupation, the colonization, and the controlling of another people and their land by another military power. Postcolonialism analyzes the social, cultural, economic, and political relations between the imperial colonizer and the colonized people, exploring the human relations between the colonizing nations and the subaltern peoples. It shows how some races assigned themselves a civilizing mission that they thought gave them the right to colonize what they considered as other inferior and less civilized peoples. Postcolonialism addresses the political identity of a colonized people and how it was affected by the culture of the colonizer. It concentrates on the social, political, and cultural perspectives of the colonized subjects and their creative resistance to the culture of the colonizer and the us-and-them binary relationship between the colonizer and the colonized.

Historically speaking, postcolonialism had its roots in colonialism and imperialism. Colonialism started as a result of the belief of some nations in their cultural, scientific, social, military, and political superiority over other nations which they viewed as inferior and in need of other more advanced powers to control them. Though there is no agreement on the starting point of colonialism, it is now generally agreed that colonialism started around the 16th century when some European colonial powers began to expand by occupying other territories outside their national borders. This process reached its peak in the 19th century. According to Said (2000) colonialism as a political concept was espoused by the French philosopher-historian Joseph-Ernest Renan who wrote in 1871 that "the regeneration of the degenerate races, by the superior races, is part of the providential order of things for humanity" (pp. 418-419). This racialist view dominated the 19th century European world view and was used as a pretext for justifying the occupation and domination of other lands and peoples.

The dismantling of colonialism or imperialism began around the second half of the 20th century. Postcolonial studies emerged as a result of this movement. It was Frantz Fanon who first drew attention to 
colonization not merely as a matter of political domination and economic exploitation but more as a system of exerting power by depicting the colonized as inferior and immature in comparison with the superior and civilized colonizer. By expressing this view, Fanon anticipated the more fundamental postcolonial theorists of the 1970s, 1980s, and 1990s such as Edward Said, Gayatri Spivak, and Homi Bhabha. Sawant (2012) points out that "from the late 1970s, the term [postcolonialism] has been used by literary critics to discuss the various cultural effects of colonization" (p. 120).

As a literary theory or a critical approach, postcolonialism or postcolonial study deals with the literatures produced by the countries which were once colonies of imperial powers. It attempts to analyze, criticize, and respond to the legacies of colonialism and imperialism. It examines the colonial and the postcolonial aspects of the lives of the formerly colonized peoples and addresses the postcolonial identity and culture of the decolonized and their relationship with the former imperial powers. Furthermore, it discusses the political, economic, and cultural impact which the imperial and hegemonic powers have had on the decolonized countries. Though postcolonialism may include that part of Anglo-American literature that views the peoples of the Orient from a favourable perspective like, for example, E. M. Forester's A Passage to India, or Frederick Jameson's Third-World Literature in the Era of Multinational Capitalism, it usually excludes literature that represents either English or American viewpoints. Instead, it concentrates on the literatures of societies that were once dominated by European imperial powers.

Postcolonial literature, therefore, critiques and challenges colonialist literature which justified imperialism and colonialism. Originally, colonialist literature was used as a medium to enhance the colonial civilizing mission. Macaulay is reported to have said that "a single shelf of a European good library is worth the whole native literature of India or Arabia" (quoted in Sawant, 2012, p. 124). In contrast, postcolonial literature offers a literature wherein the writers produce works that articulate and celebrate the postcolonial identity of the decolonized peoples while maintaining pragmatic connections with the previously colonialist country. It would therefore promote the development of a native postcolonial cultural identity after decolonization. Postcolonial writers try to respond to the dominant ideologies and discourses of the colonists by destabilizing their colonial argument which they previously used to subjugate what they saw as inferior colonies. In their endeavour to counteract this attitude, postcolonial writers try to prove that the culture of the colonized country is not really inferior to that of the imperial power. They also articulate and celebrate the identity of the decolonized while trying to establish a new relationship with the imperial country. By means of their postcolonial literature, the writers of the decolonized countries reply to the imperial powers' misrepresentation of their indigenous culture. In the words of early theorists of postcolonialism, they "write back to the center" of the empire with a view to forming and establishing their national identity after decolonization (Fanon, 1983; Ashcroft, Griffiths, and Tiffin, 2004). Postcolonialism tries to critique the argument of imperial powers and establish new relationships between what used to be the colonizer and the colonized. To that end, postcolonial critics try to destabilize and challenge the dominant ideologies of the West which colonial powers have used to subjugate other peoples so as to serve their economic, political, and cultural interests. Postcolonialism allows the subaltern peoples to speak for themselves by giving them a voice of their own that enables them to set up a more balanced relationship between the colonists and their colonial subjects. Thus, the rejection of Western hegemony forms the cornerstone of postcolonial discourse which in turn creates new space for marginalized peoples and societies or the subalterns. 


\section{Review of Theoretical Literature}

Notable theorists of postcolonialism include such figures as Frantz Fanon, Edward Said, Homi Bahbaha, Gayatri Spivak, Aijaz Ahmed, Frederic Jameson, and Robert Young, among many others. Obviously, these critics come from different persuasions and continents. Fanon, Said, Spivak, and Bhabha, and Aijaz Ahmad were raised in the Third Word but studied and wrote their works in the West. Frederik Jameson, Robert Young, and some others come from a Western cultural background.

Frantz Fanon is an important figure in the history of postcolonialism. He called for tough resistance against foreign occupation and outside hegemony. In his two canonical works Black Skins and White Masks (1961) and The Wretched of the Earth (1963), Fanon viewed colonialism as essentially destructive. For him, the colonized must resist colonial subjugation and dehumanization. In his first book, Fanon examined the dangerous psychological effects of colonization on the indigenous population. In his second work, he dealt with anti-colonial sentiments and the ways of addressing decolonization and new paths to social justice.

In his Orientalism (1978) Edward Said conceptually addresses the oppressed subaltern man and woman to explain how the Eurocentric perspective of Orientalism produced the foundations and the justifications for the domination of the other, by means of colonialism. Said argues that European imperialists applied the concept of "Orientalism" to suppress the social, cultural, and intellectual traditions of the countries they occupied in order to impose on them their own norms and values. In this attempt the colonists viewed their culture as being superior to that of the colonized with the aim of making it easier for them to control other countries and their peoples. As Parker (2008) illustrates, in Said's model, Western discourse constructed the East as sensual, lazy, exotic, irrational, cruel, promiscuous, seductive, inscrutable, dishonest, mystical, while constructing the West as rational, hard-working, kind, democratic, moral, progressive, and technological (p. 248). Through a discourse that created an "us" and "them" binary social relation, the West represented the Orient as backward and irrational lands, and, therefore, in need of European help to become modern, in the Western sense. Said concludes that the discourse of Orientalism is Eurocentric, and does not seek to include the voices of the Oriental peoples, the subalterns themselves.

As Fanon was the originator of postcolonial aesthetics, Said can be considered the major theorist of postcolonial studies. In Said's works, the concepts Orientalism, colonialism, and imperialism are closely interlinked and become almost interchangeable and all are geared to one sole end, the domination of other peoples and their countries. Drawing upon Michael Foucault's notion of discourse (1972), Said argues that Western discourse created a dichotomy, a binary opposition between Europe and its "others". Said's aim was to show how knowledge about the East was a way of dominating it. Said defines Orientalism as "a Western style for dominating, restructuring, and having authority over the Orient" (Orientalism, 2003, p. 3).

Gayatri Spivak also introduced the postcolonial term "subaltern" to refer to the peoples outside the hegemonic power structure of the colonist power. Originally, she borrowed the term and the concept from Antonio Gramsci's work on cultural hegemony where the term was used to refer to the groups that are excluded from a society's structure for political representation and thereby not having a voice in their own society (Parker, 2008, p. 256). Later, the word was used to denote the colonized people of the Indian subcontinent particularly Indian subaltern women who could not have a voice or, in the words of Spivak, could not "speak". In postcolonial studies "subaltern" has been used as a Eurocentric method for studying the peoples of Africa, the Middle East, and Asia. In its more general applications, the concept is now used to refer to the lower classes 
and social groups who are marginalized. Spivak cautioned against a too-broad use of the term, against ignoring subaltern peoples as "cultural others" and against the idea of representing the subaltern peoples as mimics of Western colonists (De Kock, Interview, 1992, pp. 45-46).

Praising Edward Said for his ground-breaking Orientalism, Spivak emphasizes that Said's work paved the way for the current interest in "marginality" and created the ground for the marginal. In her article, "Can the Subaltern Speak?" (quoted in Williams \& Chrisman, 1994), Spivak raises a question to which she does not give a definitive, clear answer. Spivak's conception of the subaltern covers both subdued women and subverted social groups and minorities anywhere. Her article may suggest that the subaltern Indian woman may not be able to speak, not so much because she cannot use words as because nobody is ready to listen to her. However, when it comes to the suppressed peoples and social groups in general, her position remains ambiguous and indefinite. As Parker (2008) clarifies: "Spivak does not answer 'No' to the question 'Can the subaltern speak?'... She sees the question as open, continuous, and unanswerable” (p. 259).

The postcolonial critic Homi Bhabha is also one of the major proponents of postcolonialism. Drawing upon Derrida's theories of deconstruction, he defined the subaltern social groups as oppressed racial minorities whose social presence is crucial to the self-definition of the majority group. Though the majority group has the upper hand in the social power relations, the minority groups are also in a position to subvert the authority of the social groups who hold hegemonic power. According to Bhabha $(1994$, p. 113) the new polarity of a colonialist and a colonial country results in disintegrating rather than integrating different entities. Bhabha, therefore, suggests "hybridity" as a means of bridging the gap between disparate entities. He utilizes the concept of hybridity to stress the interdependence relationship between the colonizer and the colonized. For him, hybridization is a kind of political and cultural negotiation between the colonizer and the colonized. "Cultural hybridity" enhances the mutual interaction between the West and the East and is an essential component in postcolonial discourse to bridge the gap between the two poles. Bhabha sees Said's Orientalism as excessively binarized and "describes the colonized and colonizing worlds as hybrid, as against Said's sense of one culture thinking about its opposite culture" (Parker, 2008, p. 250). In postcolonial discourse, hybridity is a widely used synonymy for cultural multiplicity.

Connected with hybridity are two concepts which were developed by Bhabha as part of his contribution to postcolonial theory. The first concept "mimicry" is borrowed from psychoanalysis and used by Bhabha to describe a state of ambivalence, a continual fluctuation between wanting one thing and wanting its opposite such as the mix of attraction and repulsion that characterizes the fluctuating relationship between the colonizer and the colonized. The same concept has been a popular term in postcolonial studies to describe the blurred relationship that results from the colonized's mimicry of the master by adopting his cultural habits, values, morals, and practices but without ever reproducing or assimilating the same traits. Rather, it results in a "blurred copy" of the original; hence, its posing a serious threat. In this ambivalent and unstable situation, the mimicking people become a kind of anti-colonial resistance. In this way, mimicry becomes simultaneously a means of subversion and resistance (Bahbaha, 1994, pp. 35, 87).

Apart from the above mentioned major figures of postcolonialism there are a good number of other more recent postcolonial theorists. One of these is Aijaz Ahmad, the Indian-born Marxist literary theorist and critic. It was not until the publication of his study In Theory: Classes, Nations, Literatures (1992) that a systematic critique of postcolonialism's fields of study from a Marxist perspective became available. Another prominent postcolonial figure is the American Marxist critic and political theorist Frederic Jameson. His Third-World 
Literature in the Era of Multinational Capitalism article (1986) has given poignancy and vigor to postcolonial literature produced by formerly colonized nations and has tied the literary production of the Third World to the Western interpretive literary canon. Furthermore, the contributions of the British postcolonial theorist Robert Young to postcolonial theory have also been insightful and helpful. His work has traced the history of liberation movements around the world and over a long period of classical European colonialism.

In addition to the above mentioned theorists, there have been a good number of writers from different parts of the world (particularly Africa) whose works show a critique of colonialism no less vigorous than that of the theorists. These writers include the Nigerian playwright Wole Soyinka who takes pride in the dominant African culture in his works and the Kenyan novelist Ngugi wa Thiong'o who argues that African writers should stop writing in the European languages that the colonizers forced on the colonized peoples and begin writing in their African languages (Parker, 2008, pp. 246-247). Even a more prominent postcolonial writer is Chinua Achebe who viewed himself as writing not in British English but in African English. To this long list of postcolonial writers can be added the works of postcolonial writers in Latin America such as Jorge Borges and in the Middle Eastsuch as Tayyeb Saleh who often view the relationship between their national literature and European literature as more oppositional than harmonious.

\section{Review of Empirical Literature}

The area of postcolonial literary studies gained prominence and greatly expanded in the late 1970s after the publication of Edward Said's Orientalism (1978). Furthermore, the growing currency of the now popular term "postcolonial" has been consolidated following the appearance of The Empire Writes Back: Theory and Practice in Post-colonial Literatures (1989) by Bill Ashcroft, Gareth Griffiths, and Helen Tiffin. Since then, the term had begun to replace the other terms "Commonwealth" and "Third-World" literature to designate the literature of Europe's former colonies. Research into postcolonial literature has continued in the fields of poetry, drama, and fiction particularly in the area of the novel genre. The themes that attracted most attention include power relations, cultural, political, economic, social, and scientific influence and interaction between colonizer and colonized nations. Themes of hybridity, identity, marginality, otherness, minorities, citizenship, and transculturation have also been emphasized and expanded especially after linking them with other areas such as feminism, postmodernism, capitalism, imperialism, ecology, politics, race, ethnicity, and many others.

Some of the best known postcolonial writers and critics whose works have been discussed by scholars and researchers in a large number of articles, books, theses and dissertations include Edward Said, Homi Bhabha, Gayatri Spivak, Frantz Fanon, Chinua Achebe, Buchi Emechita, Salman Rushdie, V. S. Naipaul, Wole Soyinka, Assia Djebar, Amitav Ghosh, Nadine Gordimer, Hanif Kureishi, Ghassan Kanafani, Mahmoud Darwish, and several others. More recently, the works of some Anglo-Arab writers such as Fadia Faqir, Ahdaf Soueif, Liyana Badr, Leila Al-Atrash, and Laila Halabi have been attracting attention in the area of postcolonial studies especially among university graduates as a subject for their theses and dissertations.

Fadia Faqir is a contemporary British Arab or Anglo-Arab novelist. Born in Amman in 1956, Faqir graduated from the University of Jordan and worked as a journalist before going to Britain where she got her M.A. and Ph.D. degrees in creative writing. She also translated several novels by Arab women writers besides editing some critical anthologies and serving as an academic at University of Durham, UK. Her first novel Nasanit (1986) focuses on the Palestinian Intifada and her second novel Pillars of Salt (1996) concentrates on the situation of Jordanian women during the British Mandate for Transjordan. Faqir's Pillars of Salt established 
her as an important Anglo-Arab writer concerned with the Anglo-Arab encounter during a relatively short colonial period following World War I.

Faqir's Pillars of Salt has been discussed from various perspectives such as feminism, cultural studies, and postmodernism. However, these studies tend to make scant reference to the postcolonial elements in the novel. In an online article Bouteraa (2004) makes a close linkage between societal violence against Bedouin women by their patriarchal society and the political violence emanating from local resistance against foreign occupation represented by the British mandate for Jordan in the early 21 th century. The main concentration in this article is on the societal violence and the cultural constraints against women with little attention given to military resistance against the British forces or the other themes associated with postcolonialism such as identity, hybridity, and subalternity.

In their paper entitled "The 'Unhomely' in Fadia Faqir's Pillars of Salt" Suyoufie and Hammad (2009) examine the novel from a predominantly feminist perspective and partially from a postmodern perspective with limited attention given to the postcolonial aspects of the narrative. The two authors point out how the narratives of Maha and Um Saad form a feminist counter-discourse to that constructed by the cynical Storyteller (p. 302). Approaching the novel in metafictional terms, they also illustrate how the Storyteller's tale is an obvious act of subversion and sacrilege which "partakes of the mode of desacralizing the sacred in postmodern fictions" (p. 302). In their relatively scanty representation of the postcolonial aspects of the novel, the two authors assert that Faqir "seems to transcend boundaries by allowing a global understanding and opening up to multiculturalism, which is at once diverse and enriching" (p. 209).

Al-Saket's thesis (2012) discusses the double-bind that women in formerly colonized countries suffered from, namely patriarchy and colonization with partial reference to Faqir's Pillars of Salt (1996). She argues that in the novels she has discussed, women suffer from the oppression exerted on them by the foreign colonizers in addition to that coming from their families and their society. Both sources of oppression reduce women to second-class citizens. In his "Introduction" to The Edinburgh Companion to the Arab Novel in English, Nouri (2013) argues that the aim of Faqir's novel is to "at once...challenge imperial hegemonies and systematic racisms and to affirm a cultural conviviality and coexistence" (p. 22).

In her M.A. thesis Al-Fadel (2010) studies the novel from a feminist perspective and concludes that in both Gilman's "The Yellow Wall Paper" and Faqir's Pillars of Salt "women are shown as occupying secondary roles in their patriarchal societies" (p. iv). Both stories demonstrate how women were kept confined to severely traditional female roles constructed and determined by their patriarchal cultural and social systems. As a result, these main female characters are denied a voice, an identity, and even physical freedom.

In an online article titled "Pillars of Salt, A Woman of Five Seasons and A Balcony Over the Fakihani" (2016), the writer concentrates on the portrayal of Middle Eastern women from a feminist perspective that shows them the victims of their own patriarchal society and social traditions and how they are unable to express themselves freely because their society does not allow them to speak. Similarly, in her M.A. thesis, Sinclair (2012) explores the disempowerment of women in selected Middle Eastern and African novels including pillars of Salt. The discussion focuses on the plight of women in these two areas as reflected in the oppression, victimization and violence practiced on them by their patriarchal societies and inherited traditions. In her chapter on Faqir's novel, Sinclair does not explore the impact of colonization on the life of the two Muslim women whose victimization occurs in different situations but with similar results as the two victims are forced into a mental asylum by their oppressors. 
Pillars of Salt has also been discussed by Lindsey (2008) in a short chapter in a book that focuses upon a range of postcolonial feminist creative writings affiliated to Arab-Muslim contexts. Faqir is one among a host of the female postcolonial writers whose creative works are discussed in the book as they all have dealt with Arab-Muslim woman. Lindsey's study examines Pillars of Salt from a patriarchal-postcolonial perspective.

As indicated above, a review of the literature on Pillars of Salt reveals that most of the reviews, articles, and critical discussions have concentrated on this novel as a reflection of a feminist writer's view of a patriarchal Jordanian Arab society. They tend to make scant reference to the postcolonial elements in the novel and so the postcolonial aspects have remained largely unexplored. The justification for writing this paper comes from its attempt to fill the gap in this area of academic research because in this novel the gender and political issues greatly intertwine, the one leading to the other. The following discussion, therefore, attempts to explain the close connection between the two themes and from a predominantly postcolonial perspective.

\section{Discussion}

Pillars of Salt explores the damaging effects that patriarchal and colonial systems in Transjordan in the 1920s and afterwards had on the main characters and on the Jordanian society at large. This is done through examining some issues usually associated with postcolonialism such as the marginalization of women, identity, and the cultural clash between the colonizer and the colonized. In this novel, we see how patriarchy and colonialism collude with each other against women. The novel's two main female characters Maha and Um Saad recount their individual stories of oppression and the physical and sexual violence to which they are subjected by the male figures of their restrictive patriarchal society, an oppression that is enhanced by the colonial occupation to which the country is subjected. Women's liberation and political independence are intimately connected. Both have in common a concern with emancipation, freedom (personal and civic), human rights, integrity, equality, independence, power-sharing, liberation, and pluralism. Colonialism has a mal-effect on the life of the characters and the whole society by increasing the suffering of these women and by depriving them and many others in their community from practicing their human potential.

Faqir's tempestuous protagonist Maha is a Bedouin woman from the Jordan Valley area living during a period of great political upheaval that characterized life in Jordan following the British mandate for Jordan which extended from the 1920s until 1946. Maha is a highly outspoken, unrestrained, and fearless woman who fights to be put on equal footing with that of the fiercely tempered and powerful Bedouin male and to defend the national rights of her people. The fierceness displayed in Maha's desire to fight alongside her husband Harb further illustrates her as a fiery, independent and free-spirited character. Faqir's incorporation of the political turmoil during the British mandate helps to create the dynamic power of the novel's principal character Maha, who finds herself fighting on more than one front. As Al-Fadel points out, Faqir portrays Maha as a woman whose fight is three-fold. First, she must battle the political injustices of the aggressors, the foreign men who have taken her beloved husband Harb. Secondly, she finds herself fighting her brother Daffash, who is bent on controlling her views and her ideas and on taking her land. Thirdly, she has to fight a patriarchal community which suppresses her and usurps her legal rights (Al-Fadel, 2010, p. 91).

Faqir is actually rewriting an important epoch of Jordan's history through the perspective of her female characters and from a partially postcolonial angle. Pillars of Salt is set in colonial Transjordan in the 1920s and the postcolonial Jordan following its independence in the mid-forties. Colonialism in Jordan began during World War I after the launching of the Great Arab Revolt in 1916 by Sharif Hussein in cooperation with the 
British and with the support of the Allies of World War I against the Ottomans. In 1917 British Foreign Secretary Balfour issued a letter to a prominent British Jew, Lord Rothschild, promising Britain's commitment and support for a Jewish home in Palestine. Known as the Balfour Declaration, the letter called for the establishment in Palestine of a National Home for the Jewish people.

In 1919, the Treaty of Versailles assigned Arab lands as mandates to Allied Powers. The Sykes-Picot Agreement established a framework for the mandate system which was imposed in the years following the war. In 1920 the newly-founded League of Nations awarded Britain the mandates over Transjordan, Palestine, and Iraq. France was given the mandate over Syria and Lebanon. In 1920, Emir (later King) Abdullah led forces from the Hijaz to restore his brother's throne in the Kingdom of Syria. However, the French mandate over Syria was already well planted, and Emir Abdullah was obliged to delay his pan-Arab goals and focus on forming a government in Amman. Emir Abdullah soon succeeded in loosening the British mandate over Transjordan with an Anglo-Transjordanian treaty. In 1923, Britain formally recognized the Emirate of Transjordan as a state under the leadership of Emir Abdullah. The treaty stipulated that Transjordan would be prepared for independence under the general supervision of the British high commissioner in Jerusalem, Palestine, and recognized Emir Abdullah as head of state. Between 1928 and 1946, a series of Anglo-Transjordanian treaties led to almost full independence for Transjordan. In 1946, Emir Abdullah negotiated a new Anglo-Transjordanian treaty, ending the British mandate and gaining full independence for Transjordan (Massad, 2001, pp. 1-10).

Pillars of Salt explores the intertwined patriarchal and postcolonial paradigms. The story of the main protagonist the peasant woman Maha begins with the death of her mother in 1921, the year in which the mandated Transjordan was established by Britain. The historical chronology given at the start of the text lists two rebellions against the British mandate administration. The first occurred in 1923 and was led by Sultan Ibn Adwan in the Jordan Valley area. The second took place in 1926 when the villagers of Wadi Musa, a town in the southern part of Jordan, protested against heavy taxation. The death of Maha's husband Harb (whose name means war) happened during one of these rebellions after fighting a fierce battle with the British Royal Air Force (RAF). According to Moore (2008, p. 105), the Wadi Musa rebellion is rendered fictionally as the event that killed Maha's lover who fights the British forces in the early years of their presence on the Transjordanian soil.

In a retrospective manner, the fictional narrative begins in Fuhais Mental Hospital in 1946 or thereafter, the year in which Jordan gained its independence. It is in this asylum that Maha relates her historicized story as well as the story of her roommate Um (mother of) Saad, a Syrian-born resident of Amman. Maha's incarceration in a prison/asylum represents both the unjust society and the ruthless colonizers that deprive the individual from his/her freedom and place him/her under permanent surveillance but cannot entirely suppress their voices or obliterate their perspectives. The two women in this novel are subjected to different kinds of suffering, but in the end their thwarted struggles end them up in a mental hospital. Faqir illustrates this "double jeopardy" by clearly depicting the abusive and physical actions inflicted upon them by not only the male figures in their personal lives but also by the foreign institutions under whose "care" they are placed. For example, the English doctor in the mental hospital, Dr. Edwards, insists on silencing these women's much-needed therapeutic conversations by subjecting them to forcefully-imposed electrical shock treatments ( $\mathrm{p}$. 207). As Moore (2008) points out, "The inclusion of a British doctor who 'rules us like a king' consolidates an alignment of two contiguous frames of dominance, and containment: local patriarchy and neo- (colonialism)" (p. 107). 
The question is: Can these women speak? In fact, they speak a lot, but nobody listens to them. The subaltern cannot speak because their words cannot be properly interpreted. Hence the silence of the female in the novel is not the result of her lack of articulation but the outcome of the refusal of society to listen to her and interpret her words appropriately. Um Saad's marginalization and her difficult life with her bad husband are somewhat connected to her situation as an immigrant who came from Syria because of French colonizers who occupied the country. Because of the lower status of her father as a refugee, she is marginalized and nobody cares about her or is eager to marry her, so her father was ready to marry her to the butcher whom she did not like. Her problem is further aggravated by the British colonizers in Jordan. Dr. Edwards, the English psychiatrist who is supposed to be helping her, is actually contributing to her problem. As we are told in the novel, he tries to suppress Um Saad and her companion Maha telling them not to speak: "Dr. Edwards entered the room quietly, interrupting Um Saad's story. You never stop talking" (p. 207). The English doctor also cuts off Um Saad's hair against her will (pp. 207-208). In this way, he collaborates in the mistreatment of the two women after labeling them as "mad". Both acts show how societal violence is further aggravated by the oppressive and subversive treatment of the colonizer.

Maha's tale takes us back to the early 1920s as the beginning of her love relationship with Harb and the start of the British mandate for Jordan. Harb, we are told, has joined the secret rebellion against the English colonizers. He and his companions have started a rebellion against the British mandate and what he considers their heavy taxation of the poor population. He tells Maha that the English, like the Turks, impose heavy taxes on the poor people and in arrears:

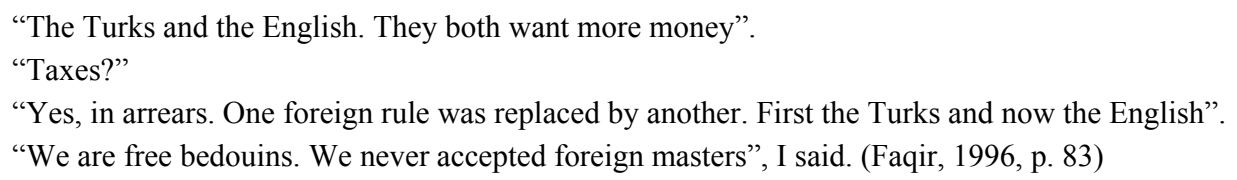

As the above quotation indicates, Harb sees the British forces in Jordan as an occupation. He therefore joins the national resistance against the British mandate to liberate the country from any oppression or subjugation. Harb is also furious when he looks in the direction of the west bank of the Jordan River and sees English soldiers on the other side of the river: "He looked at the west bank and shook his head like an angry horse: "No, I am not like your brother Daffash" (p. 53).

The novel traces the rise of the local resistance to British policy and shows how the conflict culminates with the death of Harb. However, we do not see much of Harb in the area where he lives for he is most of the time away fighting against the English forces or what is called "the English mandate" (p. 55). On one occasion, we see him well received by his wife Maha, who "ran to meet the twin of [her] soul" (p. 82). He had received a deep wound after a big battle with the English soldiers, and Maha was trying to tend his wounds. As Harb gallops away for the last time, Maha prays for protection over Harb: "Go. May the eye of Allah guard you" (p. 84). However, Harb is soon killed in an air raid by the English planes or what is called in the novel "metal eagles" (pp. 111, 118).

Caused by "the eggs dropped from the metal eagles" (i.e., bombs dropped from fighter planes), Harb's death is depicted as violent and gruesome. The description of Harb's and his fellow horsemen's death is rendered in the devious and spiteful Storyteller's narrative; nevertheless, it reveals the horror and great calamity caused by the incident: "The bombing split open the bodies of men, exposing their entrails... Black smoke 
filled the area, the stink of burnt flesh and blood filled the air" (p. 115). On one level, Harb's horrible and frightful death is a clear evidence of the great impact that the political-military violence has had on the domestic life of this Bedouin society. On another level, Harb's death is presented as an honorable act when seen from the perspective of Maha, who sees it as a great loss for her. Maha's strong reaction to the sight of her husband's mutilated and burnt corpse and her simple but dignified burial of her husband's remains add a sense of deep grief to her uncontrolled sorrow over the death of her beloved fighter. Even the Storyteller's vindictive account of the death scene inspires an honorable stature for the man who died together with other fellow fighters during their struggle against the occupier:

She kissed his lips then shrouded his body with soil until he was completely buried. The faint light of the dying sun made the corpses look bigger, darker, and more haunting. She dug more soil and scattered it on the bodies of the horsemen... (Faqir, 1996, p. 116)

As for Maha, she is portrayed as a rebellious and fierce woman throughout the story. She is described as "tigress" (Faqir, 1996, p. 11), Harb's "Arab mare" (ibid., p. 83) and in more than one place, the Storyteller speaks of her as "demon", "ferocious" and as a "thorn stuck in the sides of the Arabs' enemies" (p. 2). Maha's image as a warrior appears throughout the story. When her husband Harb is wounded, Maha swears she will drink the blood of the man who wounded him (p. 83). Both Maha and Harb are fighters. "They are both warriors in their own right: Maha is struggling for independence and freedom in her society and Harb is fighting to keep his county's independence" (Bouteraa, 2004). The loss of Harb has caused Maha and her father to suffer a great deal. Maha is deeply grieved when she reflects that "the twin of her soul [i.e., Harb] has departed from this earth" (ibid., p. 117). In one sense, Maha's son Mubarak is born of this political violence and this may show that this cycle of violence would continue, an act clearly symbolized by Maha's keeping Harb's dagger under her pillow (p. 124). All indications show that Maha will continue to live under this emotional turmoil. Furthermore, Maha's defiance of her society's subversive rules and her brother's oppression underscores her role as a warrior in her own right.

On the whole, life in the Jordan Valley where the events of the novel take place is characterized by violence on both the social and the political-military levels. As depicted, the Bedouin society is highly militant and prone to violence. Harb has spent his life fighting the English; Maha's father has his English rifle as one of his meager belongings, and Daffash has his pistol (p. 9). Women are raped and their human rights violated and the cycle of violence goes on unabated. Social violence against women is closely connected to the political turmoil at this period in time. For example, Daffash beats Maha because she rebuked him after discovering she had been feeding the people who had "chewed on [her] husband's flesh" (ibid., p. 162). In this way we see how the military conflict leads to domestic violence and the close tie that connects them.

For her part, Um Saad makes her personal suffering political by associating it with the French occupation of Syria. In the late 19th century and early 20th century Jordan received several waves of immigrants. Syrians and Palestinians migrated to Jordan to escape over-taxation and feuds, while Muslim Circassians and Chechens fled Russian persecution to settle in Jordan, Syria, Iraq, and Turkey. The novel shows that other countries in the Middle East were going through the same process as that of Jordan, being occupied by a foreign power and struggling for independence. We see the suffering of the Arab population in Jordan and in Syria as a result of the British and French occupation of the two countries respectively. Um Saad, for instance, talks about her childhood in Damascus before she was forced to flee to Jordan due to her father's activity as a freedom fighter 
against the French mandate in Syria. Because of murder and bloodshed, Um Saad's family had to leave Syria to Transjordan (ibid., p. 37). Um Saad explains how her hatred for the French stems from the bad way they treated her father (p. 37). She hoped that moving to Transjordan would cause her father to stop fighting the French and leave her and her mother alone (p. 37).

As there is a popular opposition to the French colonialism in Syria and Jordan, there is also strong opposition to British colonialism in Palestine where there is fierce resistance by the Arab population against the establishment of a Jewish state on Palestinian land. In an unexpected condemnation of the Balfour Declaration of 1917, the cynical Storyteller sarcastically narrates:

My friend the Englishman told me, was an English lord who lived in a faraway land called Britain... According to the Englishman, Lord Balfour gave the piece of land extending west of the Jordan River to a tribe without dwellings of their own. A land without people for a people without a land, he thought. (ibid., p. 29)

As depicted in the novel, Palestinians suffered tremendously under the shadow of the British mandate and Britain's colonial past if only because of their dispossession of their native lands. The Balfour Declaration of 1917 proclaimed "the establishment in Palestine of a national home for the Jewish people", an outrageous disregard of the Palestinian human rights. In this way, the destructive effect of the British mandate over Transjordan links up not only with the French mandate over Syria but also with its even more destructive impact on Palestine and its people.

This linkage and this reaction form a kind of "writing back" against the British and French mandates over the Arab lands and the colonial past of the two imperial powers. A further implication though is that Israeli occupation of Palestine can be understood as being colonial in nature, and more specifically, of the "settler colonies" type. As Parker (2008) explains,

In settler colonies... the colonizers move in permanently, and they and their descendants often grow far more numerous than the people they colonize... Sometimes the settlers forcibly or culturally limit outnumbered indigenous peoples to specific areas, where they are surrounded by settlers in internal colonies. (ibid., p. 2420)

Said (1993) also notes, "There is an unmistakable coincidence between the experience of Arab Palestinians at the hands of Zionism and the experiences of those black, yellow, and brown people who were described as inferior and subhuman by nineteenth century imperialists" (ibid., p. 68).

In the fight against a colonial power, the land becomes an important symbol of national struggle. In postcolonial literature the land often becomes the center around which the events are concentrated. Postcolonial discourse thus offers an appropriate framework to address the connection between the landscape and national mythologies, in particular the way narratives of colonial history are revisited, undermined, and reshaped. As Dale and Gilbert (2010) explain: "One of the principal means of resisting imperial narratives and rewriting the self...is through the refiguring of place, and analyses of the relations between place, language and subjectivity have been central in criticism of post-colonial literatures" (quoted in McWilliams, 2010, p. 3). In Pillars of Salt, the land is invoked as a symbol of national feelings and national identity and is utilized as a form of resistance to the colonizer. The land is greatly emphasized as part of the writer's attempt to underscore the Jordanians' connection to their land and a step towards initiating some political and cultural resistance that draws upon the power of national emblems and natural symbols to reinvigorate a move towards resisting all forms of occupation or colonization. Thus, there is close interdependence between the land and national identity and consequently between them and political independence. As two interdependent forces, the land and humans 
become inseparable tools in the fight against colonization. Despite the attempts of the colonizers to separate the Jordanians from their lands, the nationalist characters remain firmly attached to their land own land. Even more, the frequent references to the land as well as to its flora and fauna further evoke the characters' sense of rootedness in their own land. Resistance comes as a result of this close and intractable bond between the characters and their land. Thus we see only the characters that are attached to their land such as Maha, Harb, and their father fighting the occupation.

As a matter of fact, Maha and Harb are united in their attachment to the land; Harb is protecting the land which Maha is cultivating and taking care of. We sometimes see Maha clearing the stones and the weeds from the soil (Faqir, 1996, p. 132). Maha becomes both emotionally and physically connected to the land. Finally cheated of her land by her brother Daffash, who has been collaborating with the English, Maha is forced to flee to the mountainside from which she soon returns to fight for her rightful inheritance and to look after her son. Ironically, it is because of this that she is sent to the mental asylum. In taking the land from Maha, Daffash is doing something similar to what the English are doing to Harb, taking the land from its legitimate and appropriate owners. Maha is dispossessed by her brother, who gains support from the colonizers, and Um Saad is deprived of her rights because of the patriarchal system and the unequal laws of her society that do not change much with the liberation from the British mandate.

Throughout the novel, there is an attempt to explore the question of national identity. Naturally, the reevaluation of a national identity is an essential result of the struggle of a country that has gained independence from a colonial power. The contrast between Harb's and Daffash's attitudes towards the land and the colonizer sparks a debate about national identity, a common theme in postcolonial literature. As Loomba (2005) points out, "Gramsci argued that the ruling classes achieve domination not by force or coercion alone, but also by creating subjects who "willingly' submit to being ruled" (p. 29). In Pillars, the people the colonizer deals with represent two different attitudes. While Harb is opposed to the colonizer and is fighting the English forces in his country, Daffash is collaborating with the English and is ready to succumb to the colonizer. Harb and Daffash represent two opposite symbols of the Jordanian society under the British mandate. They show that some people benefited from the British colonization, collaborating and working with the colonial powers in the Middle East while others led a violent struggle to push the British out of their lands. Harb is a Bedouin fighting against the British occupation of Jordan and Daffash is a Bedouin who aspires to a British way of life. Harb is an Arab symbol of resistance to colonization and he dies fighting for his land. On the other hand, Daffash collaborates with the occupier and dreams of being British, wrongly believing that the British are his friends. Daffash wanted "to move towards the white man and his bundles of money" and desired to get married to Rose Bell, an English girl who "gave the Bedouin horseman a shoulder as cold as her homeland" (p. 60). Daffash owes his loyalty to his masters, the English and is ready to sell his land to them (p. 7); and so he was rewarded generously by them. Like Harb, Maha hates the English because they had killed her husband (p. 7). Even more, she hopes that her son will eventually take revenge against them as well as against his uncle Daffash. Maha does not like her brother Daffash and his English friends for they bring damage and destruction to the whole region.

This situation can be further explained in light of Bhabha's concept of "mimicry" and "cultural hybridity". As mentioned earlier, colonized peoples often end up mimicking their colonizers, adopting the colonizer's language and educational and governmental systems, and other lifestyles. However, mimicry can come from two different directions, with the colonizer also imitating the colonized though on a smaller scale. The 
commingling of these forms of mimicry produces what Bhabha calls "cultural hybridity" or what is generally labelled cultural multiplicity in postcolonial studies. In this novel we see how Daffash imitates the colonizers and how the colonizers subscribe to an indigenous system of gender discrimination and patriarchy as reflected in the above-mentioned British doctor's treatment of his two patients, Maha and Um Saad.

Another element of postcolonialism explored in this novel is cultural identity. A high degree of cultural tension exists between the local inhabitants of Jordan and the English colonizers. Maha speaks of the negative effect of the English mandate over Jordan: "The English tried to change our lives and our land, but failed. Occupation was like a thin cloud, which was blown away by the wind" (p. 195). There are also sharp differences between the English and the natives, the colonizers and the colonized. Western women look different and remain strangers to the area. When Daffash invites his English friends to Maha's wedding, English women behave differently:

They were women and I was a woman too, but they were so different. One was wearing a tight dress with a wide, shamefully short skirt... Every part of the woman's body was revealed by the light material... The shame of it!... These women were not shy of showing their bodies off to gazing men. (Faqir, 1996, p. 33)

Um Saad also speaks of the time after the English left Jordan, having left signs of English culture: "At last, the English left our country after building clubs which no one could enter and strange-shaped toilets which no Muslim could use" (ibid., p. 177).

Finally, Maha and other women of the village of Hamia celebrate the departure of the English with great jubilation (pp. 200-201).

On the other hand, some people find themselves collaborating with the colonizer and benefiting from occupation. Samir Pasha is friendly with the English and Daffash is presented as his "slave" (p. 133). As a result, he is isolated from his local community and lives separate from other people with an obvious sense of superiority and condescension. His splendorous house stands out high among other humble houses in the neighborhood: As Maha says: When we reached the top of the mountain, the view of the valley was so clear that it hurt the eye. Humble mud houses huddled together and a large white house hovered over them. By Alla, "whose house is that?"

"It's the new house of Samir Pasha. Work there, your brother" (p. 145).

He also arrives at the house of Harb's father in a Land Rover and with his unusual dress, he looks a like a foreigner (p. 153). Thus we notice some cultural and social barriers separating the Jordanians from the colonizers and the rich Jordanians from the poor Jordanians despite the attempts to bridge the gap between the opposing sides.

In their treatment of the local people, the colonizers make a clear discrimination in favour of those who collaborate with the English forces. For example, when the English lady working at Fuhais Mental Hospital decided to allow entrance only to English nationals, Daffash expected to be allowed in because of his previous services to the English, particularly his work in translating Arabic for English travelers:

The blonde woman said in timid Arabic... "Entrance for the English only".

The dark woman asked in her watered down Arabic, "What about officer's friends?"

Daffash twisted his thin moustache and said, staring at the blonde, "What about me? I've spent a long time translating old Arabic inscriptions for travelers".

The blond patted him on the shoulder and said, "You are an open-minded Arab. Not many of them around". (ibid., pp. 40-41) 
As a whole, the novel highlights the cultural and political collision between local Jordanians and the Mandate authorities. Furious about her brother's collaboration with the English, Maha exclaims: "Cursed. Slave to the English" (p. 164); and later, she tells him: "I don't talk to servants of the English" (p. 217). This highlights the tension between the British and their colonial subjects.

The confrontation between the colonizers and the locals comes to a head when local village women are recruited to prepare a big feast for the Pasha and his guests who have been invited by Daffash, one of the Pasha's men and great collaborators. After the feast, Samir Pasha asked Maha to "come to his farm on Friday to give his cook a hand" (p. 153). He wanted to have taste of a true Bedouin mansaf. When Maha arrives in the Pasha's palace, she feels amazed at the strange sight: "It was a magnificent building with gardens full of all kinds of flowers and trees" (p. 154). The Pasha had invited some guests and Maha was asked to come to take an active part in preparing the feast. The guests turn out to be the "English masters", the English mandatory force in Jordan. Maha is surprised when she discovers that the guests are the English officers who had killed her husband Harb (p. 161). She begins to blame herself and her brother for cooking for those people: "Shame on you. Daffash, the son of dog. I did not know I was cooking for the English" (p. 161). In a fit of strong passion, Maha spits in the face of one of the officers as a way of venting her anger and seeking vengeance on those who had killed her husband (p. 162). Maha repeatedly accuses Daffash of being associated with the enemy that killed her husband, the British. Finally she cries: "Curse the English and their metal eagles [i.e., RAF planes]". As a response to Maha's insulting the English guests, Daffash beats Maha severely and breaks two of her teeth. She falls to the ground shouting at Daffash: "Cursed. Slave to the English" (p. 164).

Maha's frustration and intent on revenge do not stop there. As mentioned earlier, she hopes her son Hakim would take revenge against those who killed his father and slapped his mother (p. 171). Furthermore, Daffash's old father vents his anger against the English. He chides Daffash and rebukes him for being a slave of the English and Daffash leaves the house feeling humiliated. Later, and as a reaction to Daffash's collaboration with the English colonizer, the father gives the land he possesses to Maha because he believes Daffash does not deserve to inherit the land (p. 173).

As in her other works, Faqir draws upon her own personal experience in the writing of this novel. In an interview with Lindsey Moore (2011), Faqir reveals how she lived close to an English club from which Jordanians were not allowed to enter (p. 1). This experience is central in her portrayal of the colonizer-colonized relationship where some places are restricted only to the English residents. In addition to Um Saad's narrative about the barring of Jordanians from English clubs (p. 117), we are told by Maha that the English residents in Jordan had their own religious and recreational buildings which Jordanians only heard about and could not enter: "The city people were talking about the English clubs, captains, and churches. I had never set my eyes on any of these" (p. 40).

In drawing upon her personal experience, Faqir tries to be as objective as possible. This objectivity is partially achieved by utilizing a multilayered and a multicultural narrative perspective. Technically, the novel avoids third-person editorial omniscience and relies more extensively on the use of a multiple narrative method that includes the viewpoints of two female narrators and a Storyteller who acts as a voyeur watching the events without being a real participant in them. In the above interview with Lindsey Moore, Faqir explains her method of using multiple narrators: 
I think the truth needs to be told from different perspectives. You arrive at $a$ truth, not the truth. If you create a multilayered narrative and have different perspectives or points of view, then you more fairly represent the issue you are dealing with. (Moore, Interview, 2011, p. 3)

Paralleling the narratives of the two principal female characters is the Storyteller's tale which shows that he too is not impressed with the British forces in Jordan. Speaking with his typically cynical, blasphemous, and sarcastic manner, the Storyteller reveals his ill feelings towards the English in the same way that he recounts a distorted and contrived tale about the principal characters:

I noticed that the plateaux were swarming with young English soldiers. They first arrived in the Year of the Lord 1921. My friend the English traveler, who turned every pebble on their plains and mountains, measured the land and then took notes, called it the "Mandate". (Faqir, 1996, p. 3)

The two women protagonists also do not hide their chagrin and disappointment with the British forces and British-run institutions in Jordan including the asylum where they are supposed to be receiving psychological treatment. All the three narratives concur on their condemnation of the "Mandate".

Besides, the novel uses language that involves code switching, lexical borrowing, historical and geographical referencing, colloquial conversations, culture-specific metaphors, and grammatical deviation as a means of accommodating Arabic language and culture and underlining the novel's postcolonial narrative structure. All these techniques and literary devices constitute Faqir's strategy of presenting her largely unprejudiced view of the colonizer-colonized relationship in a crucial and formative period of Jordan's history during the British mandate for Jordan from 1920-1946 and after.

Faqir's innovative narrative technique extends to her use of language and narrative method. She uses the oral tradition often associated with the Arabian Nights in addition to traditional modern narration. In the same interview with Moore, she points out that with Pillars of Salt, she wanted to "create something similar to what Indian authors have achieved - a hybrid English. Therefore, I used the oral tradition and the Qur'an and the Arabian Nights in the Storyteller's section" (p. 7). In this way, the Storyteller's tale becomes a kind of subtext that underlies the main narrative. Faqir further states that the Storyteller is meant to represent the Orientalist picture which she believes is an untrue picture of the East. In her view, the narrator "paints a picture of the Arabs that is not true" (p. 7). She adds: "I see the storyteller as an Orientalist in cahoots with both the colonial forces and the indigenous patriarchy - the three work hand- in- hand" (p. 7). Being a representative of foreign occupation and an undesirable old tradition, this narrator who is named Al-Ajnabi (an Arabic word that literally means "the stranger") remains a distrustful and unreliable narrator throughout the story. In using this narrator to represent what she calls the untrue picture which the Orientalists depicted of the East, Faqir is actually "writing back" to classic Orientalist texts of the colonial period. Stated more explicitly, the phrase refers to Bill Ashcroft and his collaborators' seminal work The Empire Writes Back: Theory and Practice in Post-Colonial Literature, which was meant to respond to the literary center of the colonial canon. It is no surprise, then, that we find frequent critiques of British colonial policy throughout the novel coming even from this essentially pro-West narrator.

Through the eyes of the novel's two main characters, Um Saad and Maha, we are introduced to Jordan's struggle for independence and the Westernization that followed. Um Saad explains how things changed with the departure of the English and the arrival of a new king: "They left our country and I saw the celebration and the processions from the veranda. Independence Day Festival. Cavalry, tanks, camel regiments in colorful 
uniforms, and music. Brass. "Long live the King"' (p. 177). Although the British mandate had a modernizing effect on women and men in Transjordan, introducing them to modernity, its cultural values which clashed with traditional cultural norms were mostly perceived as negative and undesirable. This is clear in Daffash's unfavorable representation in the novel. He is seen negatively when he brings some of his "Westernized" friends to the village: "My father shuffled into the room and looked disapprovingly at the uncovered legs of the city women" (p. 40). Daffash's father also complains about his son's attraction to the English and their molding: "My son is lured by the city lights. He navigates by false stars" (p. 21). In fact, Daffash dreams of being British and totally denies his Bedouin roots. He thinks the Bedouin people are backward and he looks down on them all the time; and that is why he remains alienated and hated in his own community and his family.

The modernity brought by the English is also resented by some city dwellers such as Um Saad, who critically says:

Abu Subhi, the guard of the something Jack Club, told my sons many stories about the English. How strong men would chase a brainless tiny ball for hours. How they didn't wash themselves with water after going to the toilet. By your life they just wash themselves with paper. (ibid., p. 177)

Perceived from Um Saad's and Maha's perspectives, Western modernity is seen as a violent contradiction and a rejection of Arab traditions and thus it is not well received. However, today the West and the East interact in a very different way than they used to do through the notable increase of trade and cultural exchanges as well as travel, commerce, and immigration. Most people of the 21st century in the Middle East in general and Jordan in particular have found a way of living in modernity while sustaining their traditional values. The subaltern can speak after all.

\section{Conclusion}

In one sense, Pillars of Salt is a postcolonial novel that deals with Jordan's transition from British rule to independence with most of the events covering the period before independence. The story is set within the context of historical events as well as within the conventions of postcolonial fiction. Though the novel does not follow a strict historical or chronological order of events, it gives a good account of Jordan under British mandate. We first encounter the French and British occupations of Transjordan and Syria respectively during the early 1920s. The British and French presence in the region deeply impacts the characters' lives by aggravating the suppressive effects of the indigenous patriarchy. Indeed, Pillars of Salt signals the ways in which the forces of patriarchy and colonialism are conjoined to restrict the freedom and space of the individual and the community at large both on the social, the cultural and the political levels.

The first critique of this colonial period concerns the arbitrary establishment of the British mandate by the Society of Nations in 1921, which was eventually abolished by the joint efforts of the Jordanians and the British in 1946. The mandates over Transjordan, Syria and Palestine were created regardless of the cultural, religious, ethnic, and political aspirations of the local people. Faqir clearly criticizes the British mandate in Jordan through her protagonists particularly Maha and Harb, who embody the dignity, integrity, and independence of Jordan. For the two female protagonists, colonization represents more than just a white man who has stripped them of their culture and freedom. It is equally about an oppressed and unfulfilling life that they are ultimately forced to live as a result of oppressive patriarchy and an equally subversive colonial power. 


\section{References}

Al Maleh, L. (Ed.). (2009). Arab voices in Diaspora: Critical perspectives on Anglophone Arab literature. Amsterdam \& New York: Rodopi.

Al-Fadel, M. R. (2010). Woman's image in Charlotte Perkins Gilman's “The Yellow Wallpaper” and Fadia Faqir's Pillars of Salt: A feminist approach (M.A. thesis, Middle East University, Amman, Jordan).

Ashcroft, B., Griffiths, G., \& Tiffin, H. (2004). The empire writes back. New York \& London: Routledge. (First published 1989).

Bhabha, H. K. (1994). The location of culture. London: Routledge.

Bouteraa, Y. (2004). Language and style in Fadia Faqir's Pillars of Salt. Retrieved from https://www.mtholyoke.edu/courses/mjiyad/forum/messages/211.shtml

Childs, P., \& Williams. R. J. P. (1996). An introduction to post-colonial theory. London \& New York: Prentice Hall.

De Kock, L. (1992). Interview with Gayatri Chakravorty Spivak: New Nation Writers Conference in South Africa. ARIEL: A Review of International English Literature, 23(3), 29-47.

Digole, D. P. (2012). Postcolonial: An aesthetic of subversion and reclamation. In Proceedings of National Seminar on Postmodern Literary Theory and Literature (pp. 128-134), Nanded.

Fanon, F. (1963). The wretched of the earth. (C. Farrington, Trans.). New York: Grove Press.

Faqir, F. (1996). Pillars of salt. Northampton, MA: Interlink Publishing Group, Inc..

Foucault, M. (1972). The archeology of knowledge and the discourse of language. (A. M. Sheridan Smith, Trans.). New York: Pantheon Books.

Gilbert, H., \& Tompkins, J. (1996). Post-colonial drama: Theory, practice, politics. London: Routledge.

Jameson, F. (1986). Third-world literature in the era of multinational capitalism. Social Text, 15, 65-88.

Loomba, A. (2005). Colonialism/postcolonialism (2nd ed.). New York: Routledge.

Massad, J. A. (2001). Colonial effects: The making of national identity in Jordan. New York: Columbia University Press.

McWilliams, A. (2010). Our lands, our selves: The postcolonial literary landscape of Maurice Gee and David Malouf (Ph.D. thesis, The University of Auckland).

Moore, L. (2008). Arab, Muslim, woman: Voice and vision in postcolonial literature and film (pp. 100-107). London \& New York: Routledge.

Moore, L. (2011). You arrive at a truth, not the truth: An interview with Fadia Faqir. Postcolonial Text, 6(2), 1-13.

Nouri, G. (2013). Introduction. In N. Gana (Ed.), The Edinburgh companion to the Arab novel in English (pp. 1-38). Edinburgh: Edinburgh University Press.

Oxford dictionaries. (2015). Retrieved from http://www.oxforddictionaries.com/definition/english/postcolonial

Parker, R. D. (2008). Critical theory for literary and cultural studies. New York \& Oxford: Oxford University Press.

Pillars of Salt, A Woman of Five Seasons and A Balcony Over the Fakihani. (2016). Retrieved from http://www.123helpme.com/view.asp?id=34624

Said, E. (1993). Culture and imperialism. New York: Vintage Books.

Said, E. (2000). Nationalism, human rights, and interpretation. In Reflections on exile, and other essays. Cambridge, Massachusetts: Harvard University Press.

Said, E. (2003). Orientalism. London: Penguin. (First published 1978).

Sawant, S. B. (2012). Postcolonial theory: Meaning and significance. In Proceedings of National Seminar on Postmodern Literary Theory and Literature (pp. 120-126), Nanded.

Sinclair, T. J. (2012). Beyond their control: The disempowerment of women in Middle Eastern and African literature (M.A. thesis, East Carolina University).

Spivak, G. (1994). Can the Subaltern speak? In P. Williams and L. Chrisman (Eds.), Colonial discourse and post-colonial theory: A reader (pp. 66-111). New York: Columbia University Press.

Suyoufie, F., \& Hammad, L. (2009). Women in exile: The "Unhomely" in Fadia Faqir's Pillars of Salt. In L. Al Maleh (Ed.), Arab voices in Diaspora: Critical perspectives on Anglophone Arab literature (pp. 1271-1312). Amsterdam \& New York: Rodopi.

Young, R. J. C. (2001). Postcolonialism: An historical introduction. Oxford: Blackwell Publishers. 